\title{
LA GESTIÓN TURÍSTICA DE LAS VILLAS VÉNETAS. UN MODELO DE REFERENCIA PARA LA PROMOCIÓN DE LAS VILLAS DE CARTAGENA COMO PRODUCTO TURÍSTICO
}

\author{
David Navarro Moreno \\ María Jesús Peñalver Martínez. \\ Universidad Politécnica de Cartagena. España
}

\section{RESUMEN}

La villa constituye una tipología arquitectónica que ha legado excelentes edificios a lo largo de la historia. Buena muestra de ello es el numeroso conjunto de villas existente en la región italiana del Véneto construidas entre los siglos XV y XVIII. También en otros lugares se han vivido momentos de auge en la construcción de villas, por ejemplo en Cartagena, situada en el sureste de España, donde destacan una serie de residencias de recreo, ubicadas en pleno campo y construidas con cierta singularidad arquitectónica, pertenecientes a la etapa final siglo XIX y principios del siglo XX. Lamentablemente, frente al reconocido valor de las villas vénetas, las villas de Cartagena se encuentran en un grave estado de abandono que hace necesaria la adopción de medidas para su recuperación y puesta en valor.

Se plantea por tanto esta investigación con el objetivo de extraer de la experiencia italiana en la gestión turística de las villas vénetas el principal enfoque responsable de su éxito, tomando de este modo estrategias útiles encaminadas a la promoción de las villas del campo de Cartagena como producto turístico.

Palabras clave: Villas; Véneto; Cartagena; Patrimonio Cultural; Gestión; Producto Turístico.

Recibido: 17 de junio de 2016

Devuelto para su revisión: 21 de noviembre de 2016

Aceptado: 31 de julio de 2017

Departamento de Arquitectura y Tecnología de la Edificación. Escuela Técnica Superior de Arquitectura y Edificación. Universidad Politécnica de Cartagena. Campus Alfonso XIII. Edificio ETSAE. Paseo Alfonso XIII, 50.30203 Cartagena MURCIA (España).E-mail: david.navarro@upct.es, mjesus.penalver@upct.es 


\title{
The tourism management of venetian villas. A model of reference for the promotion of the villas of Cartagena as tourism product
}

\begin{abstract}
The architectural typology of villas has bequeathed to us excellent buildings throughout history. Example of this is the great repertoire of villas existing in the Italian region of Veneto built between the fifteenth and eighteenth centuries. Also other places have been experienced a villa's building boom period, for example the city of Cartagena, located in the southeast of Spain, where there is a set of interesting villas located in the countryside and built during the late nineteenth and early twentieth century's. Unfortunately, despite of the recognized value of the Venetian villas, the Cartagena's villas have suffered a great decline in recent years that makes necessary the adoption of measures for their survey and recovery.

Thus, this project is born with the intention of extracting from the Italian experience in tourism management of the Venetian villas the causes of its success, taking thus useful strategies as a basis for any conceptual or projective approach taking as object the tourist promotion of the villas of Cartagena.
\end{abstract}

Keywords: Villas; Veneto; Cartagena; Cultural Heritage; Management; Tourism Product.

\section{INTRODUCCIÓN}

La definición de producto turístico ha ido evolucionando con el paso del tiempo adquiriendo diversos matices (Pérez-Aranda, 2015: 71). Se trata de un concepto que comenzó a gestarse en la década de los ochenta en un contexto global de reflexión sobre si el turismo podía o no ser considerado una industria (Tucker y Sundberg, 1988: 145). Especialmente interesante resulta el estudio realizado por Smith (1994: 587), que propone la idea de que un producto turístico se compone de cinco elementos: un marco físico, servicios, hospitalidad, libertad de elección, y participación, siendo el éxito del producto fruto, no de la suma, sino de la perfecta integración y combinación de cada uno de ellos.

Con estos antecedentes, siempre a partir de la premisa de que el producto turístico consiste fundamentalmente en experiencias, son diversos los autores que han continuado reflexionando sobre el tema. Así, Barroso y Flores (2006: 13) definen producto turístico "como aquella realidad integral que percibe y capta el turista durante su viaje y estancia fuera de su residencia habitual -experiencia turística-, el cual está formado por una serie de bienes y servicios, tanto públicos como privados. En definitiva, un conjunto de factores de cuya combinación resulta un carácter atractivo capaz despertar el interés de determinados grupos de visitantes por satisfacer sus motivaciones, inquietudes e intereses personales.

En este sentido, la comarca del Campo de Cartagena se presenta como un territorio con un gran potencial para ser explotado turísticamente, pues ofrece un sugerente marco de referencia tanto desde el punto de vista arquitectónico como etnográfico, caracterizado de un lado por los caseríos o agrupaciones de casas campesinas, y de otro por llamativas villas inmersas en medio de una densa e inusual zona boscosa rodeada de campos de 
cultivo (Figura 1). Estas singulares villas dispersas en las proximidades de la ciudad y de los pueblos de la zona se han convertido en puntos referenciales de la percepción estética de su campo, en hitos arquitectónicos de un paisaje cultural que, más allá del reconocido valor artístico y estético, conservan todavía legibles aspectos etnográficos y antropológicos que merecen ser descubiertos, rasgos todos ellos fruto de la sociedad burguesa del siglo pasado que supo transformar los factores de producción agrícola elaborando un entorno natural en equilibrio entre los requerimientos económico-productivos y los paisajísticos.

\section{Figura 1 \\ VILLA ANTONIA. FUENTE ÁLAMO, 1894}

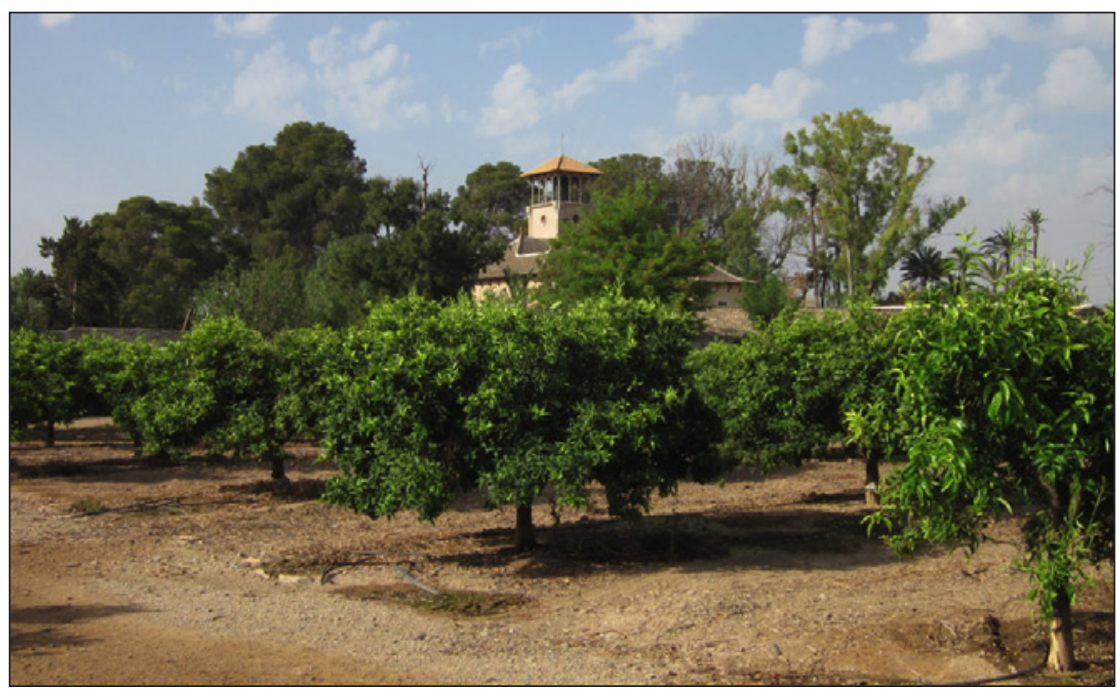

Fotografía del autor.

Se propone por ello el presente artículo en el que es abordado el estudio de la villa tanto desde una dimensión patrimonial, con objeto de identificar sus valores representativos y la justificación de su reconocimiento como bien cultural, como desde la perspectiva de la gestión turística, atendiendo a las prácticas que se han llevado a cabo en otros países para su conversión en un producto turístico.

A este respecto Italia y, en particular el producto Villa Véneta, se erige como un necesario modelo de referencia con el que confrontar el caso de estudio de las villas de Cartagena. Un simple vistazo al conjunto de medidas adoptadas para la regulación y explotación turística de las villas de la región italiana del Véneto basta para comprender que se está comparando con un proyecto de larga duración, con una consolidada cultura jurídica y una fuerte conciencia social que no puede ni debe pasarse por alto.

Por todo ello, se ha considerado necesario proceder al estudio de las estrategias llevadas a cabo para la recuperación y promoción turística de las villas vénetas. Para lograr tal objetivo, la metodología seguida ha consistido, en primer lugar, en la recopilación de las medidas adoptadas por Italia, que posteriormente han sido examinadas, sintetizadas y 
segregadas por áreas temáticas. A continuación, con objeto de extraer ideas útiles se ha procedido a la reorganización de los contenidos, lo que ha permitido identificar de forma clara los criterios y procedimientos seguidos por dicho país para la formación del producto turístico Villa Véneta.

Evidentemente, la finalidad última es la de identificar de dicha experiencia lo que ha resultado útil, así como localizar las coincidencias y diferencias respecto a la situación actual de las villas de Cartagena. Sin duda, se trata de un paso fundamental para detectar las debilidades y fortalezas del conjunto de villas cartagenero y, en base a ellas, plantear una estrategia fiable para su recuperación y posterior mantenimiento y puesta en valor, abordando no sólo la difusión de su conocimiento, sino también, y lo que es más importante, la promoción de su uso y disfrute por parte de la colectividad.

\section{LA VILLA}

Una sencilla pero acertada descripción de las construcciones que componen el patrimonio arquitectónico es proporcionada por Paul Valéry $(2004,109)$ en su obra Eupalinos o el arquitecto, al señalar que, "en los paseos por la ciudad, entre los edificios que la pueblan, unos mudos son, otros hablan; y otros, en fin, los más raros, cantan".

Esta metáfora sobre la esencia atractiva y cautivadora que sólo acompaña a determinadas construcciones nos sirve para adentrarnos en el ámbito de los edificios históricos, que sin duda alguna constituyen una parte significativa de esa arquitectura que se diferencia de las construcciones convencionales.

Es verdad que existe en las ciudades una mayor concentración de edificios que despiertan mucho más interés que el resto de construcciones de su entorno, pero también es cierto que en algunos territorios es posible ver cómo en la infinitud de su paisaje agrario emergen sugerentes villas cuya silueta se perfila entre una frondosa masa vegetal conformada por sus jardines y terrenos de cultivo.

\subsection{Aproximación histórica a la villa}

Según el Diccionario de Autoridades - Tomo VI del año 1739, una villa era una "Quinta, ò Casa de campo, donde se suele tener la labranza; pero en este sentido no tiene uso, y es voz puramente Latina, que significa lo mismo”. Una definición más reciente de la villa es proporcionada por la Real Academia Española (RAE) que, en cambio, la define como "Casa de recreo situada aisladamente en el campo".

Lo cierto es que, desde su origen, el término villa ha sido aplicado a lo largo de la historia a construcciones vinculadas al uso doméstico pero con funciones muy diferentes que van desde la sencilla edificación en el campo enfocada básicamente a cubrir las necesidades de una explotación agrícola, hasta la residencia señorial suburbana concebida únicamente para el reposo, ocio y relación social, desligada por completo del cultivo de la tierra. Evidentemente, el concepto ha sido también utilizado para designar soluciones intermedias, como villas productivas debidamente equipadas para el disfrute y estancias temporales del propietario o villas de recreo dotadas en sus jardines con espacios ideados para cultivos (Burgos, 2011: 1). 
Según Azzi (1995: 9), es comúnmente aceptada la idea general de que una villa responde a una construcción doméstica sofisticada y elegante trasladada a un entorno rural. Su finalidad es la de suponer un contrapeso a la vida urbana, caracterizada por las responsabilidades y preocupaciones del trabajo así como por un ambiente potencialmente malsano. Se presenta así la villa como un lugar donde alejarse de la ciudad, destinado tanto para el reposo, ocio y relación social como para disfrutar de las vistas y el ambiente saludable y fresco de su entorno natural.

Aunque los orígenes de la villa se remontan a Egipto, Babilonia y Persia, puede decirse que fue en Italia durante el Imperio Romano donde esta tipología residencial acabó por consolidarse bajo la forma de la villa rústica presentándose como un conjunto arquitectónico rodeado por zonas de cultivo con la doble finalidad de constituir el centro de una explotación agrícola y de ambientar paisajísticamente el lugar (Sánchez Rojas, 1986: 9). Paralelamente a estas edificaciones con vinculación directa a la explotación campesina se encontraban otras villas suburbanas de carácter monumental, concebidas como residencias de placer ubicadas a las afueras de la ciudad en zonas valiosas por el paisaje, el medio ambiente y el clima (Vera Botí, 2013: 1035).

Tras la caída del Imperio Romano de Occidente en el siglo V, las ciudades europeas se convirtieron en objeto de constantes saqueos, por lo que la mayor parte de la población se concentró en torno a las fortalezas en busca de protección. En consecuencia, la cultura de la villa cayó en abandono y acabó siendo sustituida por la del castillo medieval (Ackerman, 1990: 63). No fue hasta finales de la Edad Media, casi diez siglos después, cuando resurgió con fuerza, principalmente en la Toscana y el Véneto italianos (Figura 2). Mucho tuvieron que ver en ello Leon Battista Alberti ${ }^{1}$, y sobre todo, Andrea Palladio ${ }^{2}$, sin duda el arquitecto que de una manera más significativa ha influido en el desarrollo de esta tipología residencial, tanto en Europa como en el resto del mundo (Moriani, 2008: 91).

\section{Figura 2 \\ VILLAS DEL VÉNETO, SIGLOS XV-XVIII}
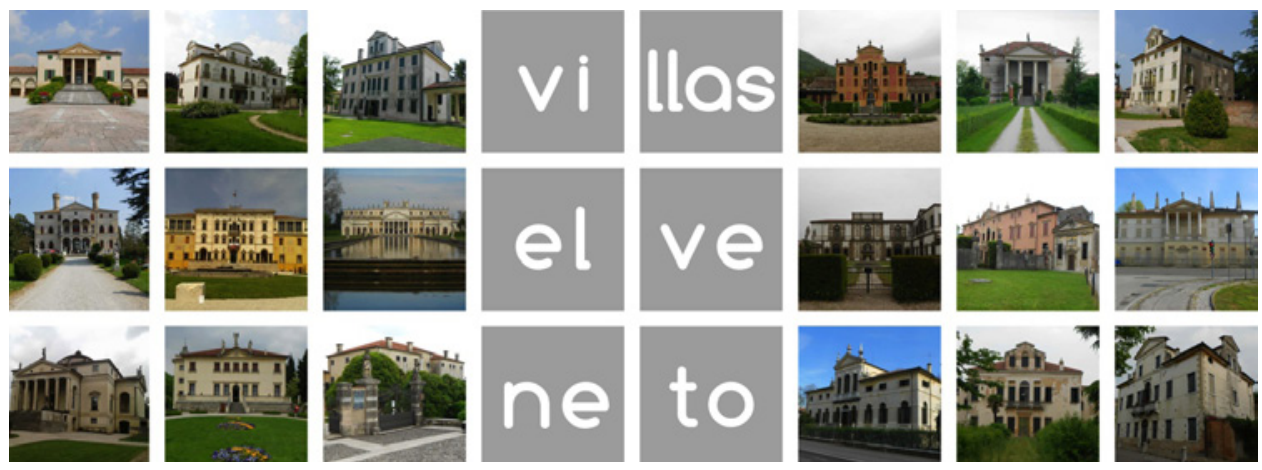

Elaboración propia.

1 De Re Aedificatoria.

2 I quattro libri dell'architettura. 
En el Cinquecento, el palladianismo acabó extendiéndose desde el Véneto hacia resto del continente europeo y otras partes del mundo, llegando a ser sumamente popular en Inglaterra durante los siglos XVIII y XIX. Más tarde, cuando el estilo comenzó a declinar en Europa, surgió con fuerza en Norteamérica, reflejando sus estrechos lazos con Inglaterra. Excelente muestra de ello son las plantaciones del sur con los edificios diseñados por Thomas Jefferson (Azzi, 1995: 313).

Por otro lado, a mediados del siglo XVIII comenzó a gestarse un cambio importante en la historia de la villa al extenderse entre parte de la alta burguesía el deseo de poseer una segunda residencia en el campo pero libre ya de una finalidad productiva. No obstante, pasó todavía un siglo hasta que se produjo la evolución en sentido moderno de esta categoría edilicia, ampliándose el concepto de villa también a una residencia de prestigio ajardinada y emplazada en ámbito urbano (Ippolito, 2009: 7).

\section{LAS VILLAS VÉNETAS Y SU GESTIÓN TURÍSTICA}

La villa constituye por su propia concepción una manifestación cultural cuyo valor es el resultado de la perfecta combinación de una serie de factores históricos, artísticos, económicos, urbanísticos, y sobre todo sociológicos, fruto de su particularidad de cubrir una necesidad que es no sólo material, sino también ideológica: la de ambientar paisajísticamente un lugar.

Por todo ello, la villa tiene un potencial suficiente para ser considerada un elemento clave en la configuración de la identidad cultural de un territorio y, al mismo tiempo, aglutina atributos más que suficientes para convertirse en un producto turístico, aspecto fundamental considerando el notable interés que el mundo del paisajismo y el turismo cultural está suscitando en los últimos años entre la sociedad occidental.

Lo que ocurre es que, al final, el patrimonio acaba conformándose cada vez más con la suma de aquellas cosas a las que se decide estar atentos y, lamentablemente en la actualidad, las estrategias de promoción turística se vienen centrando en aquellos ejemplares más relevantes y presentes en los conjuntos históricos o en el área urbana. Si bien, es cierto que existen notables excepciones como las citadas villas vénetas, consideradas uno de los símbolos de la región italiana del Véneto y convertidas hoy día en un importante recurso económico-productivo a través de la explotación de su atractivo turístico-cultural. Por este motivo se hace necesario estudiar las diferentes medidas adoptadas tanto desde la iniciativa pública como privada encaminadas a su impulsión y consolidación como recurso turístico.

\subsection{Villas vénetas: un modelo de referencia}

Respecto a las estrategias de recuperación y promoción turística de las villas, resulta necesario partir de las prácticas que se han llevado a cabo para utilizar de aquellas experiencias lo que ha resultado útil. En este sentido, la gestión italiana en la protección y valorización de las villas vénetas se convierte en un referente obligado, pues también ellas sufrieron una situación de abandono similar que comenzó al ocaso de la Serenísima República de Venecia en 1797 y se prolongó hasta el final de la Segunda Guerra Mundial 
en $1945^{3}$. Afortunadamente, en dicho momento surgió una fuerte sensibilización pública que supuso el comienzo de su recuperación y promoción de forma activa, hasta el punto de que en la actualidad se erigen como uno de los principales atractivos turísticos de la zona (Naim, 2013: 77).

Evidentemente, las villas italianas del Véneto y las españolas de Cartagena presentan ciertas diferencias constructivas y estilísticas fruto de su diferente contexto cronológico, geográfico y social. Además, se trata de dos fenómenos de diferente magnitud e intensidad, pues mientras que el conjunto véneto engloba más de 4.000 villas construidas entre los siglos XV y XVIII por toda la región, el panorama de las villas de Cartagena es más focalizado, agrupando unas 75 villas construidas entre 1840 y 1920 en torno a la ciudad.

Si bien, ambos casos presentan igualmente ciertas similitudes, no sólo por su vinculación directa a un periodo de gran desarrollo económico local con una fuerte repercusión en la arquitectura, sino también, y más importante desde el punto de vista de su gestión turística, por presentar una ubicación alejada del núcleo urbano y una profunda vinculación con la naturaleza, así como un uso preeminentemente residencial privado. Aspectos que junto al éxito en la explotación turística de las villas vénetas hacen de ellas un modelo de referencia para Cartagena, cuya ineficacia en la salvaguarda y puesta en valor de sus villas queda patente por el lamentable estado en que la mayoría de ellas se encuentran.

\subsection{El redescubrimiento de las villas vénetas}

Bajo el punto de vista de la recuperación y promoción de las villas de la región italiana del Véneto, son diversas las fases o etapas llevadas a cabo que merecen un estudio pormenorizado. En este sentido, puede considerarse que la lucha activa por su defensa comenzó en el año 1952 cuando de la mano de Giuseppe Mazzotti, director del ente para el turismo de la provincia de Treviso, se organizó una exposición fotográfica sobre las villas vénetas. Fue tal el éxito y la repercusión mediática que la muestra tuvo en dicha ciudad que debió ser prorrogada, animando el buen acogimiento de esta iniciativa a convertirla en itinerante y recorrer con ella las principales ciudades de Europa y América (Naim, 2013: 81).

Sin duda, este evento permitió difundir la importancia de dichas villas entre la sociedad local, que rápidamente se dio cuenta de su gran significado histórico y artístico y comenzó a preocuparse por su conservación.

\subsection{La declaración como bien cultural}

De este modo, sobre la base de una opinión pública ya sensibilizada en la materia, el Estado y los organismos públicos regionales decidieron incorporarse a tan ambicioso proyecto hasta el momento gestionado por la iniciativa privada. Pero, dada la gran cantidad de villas existente, casi todas de importantes dimensiones y compuestas por

3 Istituto Regionale Ville Venete [Página web], consultado: 16 de febrero 2016, http://www.irvv.net/it/ listituto/storia.html

Cuadernos de Turismo, 41, (2018), 465-490 
la residencia principal -a veces con obras artísticas de gran valor-, anexos rústicos y jardín, las necesidades eran enormes, por lo que los medios e instrumentos disponibles por la Administración pronto resultaron insuficientes. En consecuencia, para cubrir tales carencias, a partir del consorcio entre diversos organismos provinciales para el turismo pertenecientes a las regiones del Véneto y Friuli-Venezia Julia, en 1958 fue instituido el "Ente per le Ville Venete", al cual se delegaron tareas específicas de salvaguarda a través de la intervención económica -préstamos y ayudas a los propietarios- y también de vigilancia y control ${ }^{4}$.

Un segundo hito importante tuvo lugar dos décadas después cuando en 1979 el citado "Ente per le Ville Venete" fue transformado en el "Istituto Regionale Ville Venete" (IRVV), atribuyéndole también tareas de difusión del conocimiento de las villas vénetas y de fomento de su promoción turística ${ }^{5}$.

\subsection{El reconocimiento internacional}

Años más tarde llegó un nuevo impulso, esta vez gracias a la Organización de las Naciones Unidas para la Educación, la Ciencia y la Cultura (UNESCO) que, con la inclusión en 1994 de la ciudad de Vicenza en la Lista del Patrimonio Mundial y la posterior ampliación de dicho reconocimiento incorporando dos años después un conjunto de veintidós villas proyectadas por Palladio, dotó a este singular patrimonio de una enorme proyección internacional.

De hecho, el efecto UNESCO es caracterizado por convertir los elementos incluidos en la Lista en importantes focos de atracción turística, trascendiendo incluso su dimensión cultural para transformarlos en verdaderos recursos productivos. Por tal motivo, el citado organismo impone una serie de obligaciones entre las que se encuentran, no sólo las de garantizar la correcta identificación, protección y conservación del propio patrimonio cultural y natural incorporado a la Lista, sino también las de su valorización y disfrute por parte de la sociedad ${ }^{6}$.

De manera que la UNESCO ejerce una influencia constante sobre las políticas turísticas al proporcionar orientaciones sobre la regulación del turismo cultural. Precisamente, en esta materia la experiencia italiana es ya bastante dilatada, pues se trata del primer país del mundo en número de bienes incluidos en la Lista del Patrimonio Mundial. Además, este dato es aún más elocuente si se analiza el caso de las villas, ya que el conjunto de los 51 bienes italianos incorporados en la Lista del Patrimonio Mundial incluye desde Villa Adriana (s. II) y la villa romana del Casale (s. IV), a las villas y jardines Médici en la Toscana (s. XV-XVII), y las villas de Palladio en el Véneto (s. XVI), así como Villa d'Este (s. XVI) ${ }^{7}$.

4 Legge regionale n.243 del 6 marzo 1958.

5 Legge regionale n.63 del 24 agosto 1979.

6 Convención sobre la Protección del Patrimonio Mundial, Cultural y Natural, aprobada en París el 16 de noviembre de 1972. [Página web], consultado: 16 de febrero 2016, http://portal.unesco.org/es/ev.php-URL_ ID $=13055 \& U R L \_D O=D O \_T O P I C \& U R L \_S E C T I O N=201 . h t m l$

7 Properties inscribed on the World Heritage List. [Página web], consultado: 17 de marzo 2016, http:// whc.unesco.org/en/statesparties/it 
Así, siguiendo las directrices trazadas por la UNESCO, los organismos ministeriales implicados, las administraciones regionales, provinciales y municipales, y el "Istituto Regionale Ville Venete" vienen desarrollando desde hace años estrategias para la gestión de las villas palladianas, haciendo extensibles dichas medidas al conjunto de las villas vénetas, con lo que han conseguido potenciar aún más este interesante fenómeno paradigmático (Casatella, 2011: 4).

\subsection{De bien cultural a producto turístico}

Otro paso significativo hacia la puesta en valor de las villas, ya no sólo del Véneto, sino de toda Italia, lo constituye el proyecto "Valorización turística de un producto cultural: las villas", emprendido en el año 2004 de forma conjunta por las regiones del Véneto, Toscana, Cerdeña y Campaña, en las cuales abundan este tipo de construcciones ${ }^{8}$.

Dicho proyecto, desarrollado en el marco de la legislación nacional de turismo, surgió con el objetivo de idear e impulsar acciones para el desarrollo y promoción institucional del patrimonio cultural conformado por las villas para consolidarlas como producto cultural y lograr integrarlas en los principales mercados turísticos de referencia. De modo que se trató de una primera fase de trabajo - previa a la propuesta y realización de actividades de promoción turística- dirigida principalmente a conocer en qué forma la villa es percibida como atractivo turístico, tanto por parte de la demanda turística local como por parte de los principales mercados europeos. Premisa clave y fundamental de este estudio fue pues la identificación de la capacidad de las villas para atraer la atención del visitante.

Concretamente, la investigación perseguía reconocer el peso y la relevancia de la villa no tanto como bien cultural en sí mismo -cuyo valor histórico y artístico era ya reconocido de alto nivel-, sino sobre todo en términos de la mayor o menor capacidad de atraer flujos turísticos, dado que la existencia de un bien cultural no implica necesariamente que éste suponga un atractivo para la gente. El reto a conseguir era conocer en qué medida y en qué modo la villa se encontraba en condiciones de ser el motor de una nueva alternativa turística para, en base a dichos resultados, orientar las posteriores estrategias de desarrollo, valorización y promoción para convertir dicho bien cultural en un recurso turístico. Para lograr tal objetivo se procedió a la necesaria recogida directa de datos e información, tanto en Italia como en el extranjero, trabajo que se consiguió a través de diversos medios como sondeos dirigidos a turistas potenciales y a aquellos que habían visitado alguna villa, o entrevistas a operadores turísticos y agencias de viajes vinculadas con el turismo de villas (Di Cesare et al, 2006: 2).

\subsection{La consolidación como producto turístico}

Un último hito en la evolución de la villa véneta de bien cultural a bien de interés turístico se encuentra en el trabajo realizado por el gobierno del Véneto en base a los resultados del citado proyecto interregional con la elaboración en el año 2008 de un "Plan de valorización turística de las villas vénetas"

8 Deliberazione della Giunta regionale n. 3821 del 26 novembre 2004.

9 Deliberazione della Giunta regionale n. 2084 del 29 luglio 2008. 
Dicho plan previó el desarrollo de cinco estrategias, las cuales encauzaban de una forma ordenada y en una dirección precisa todas las actividades de promoción turística de las villas ${ }^{10}$ :

- adopción de una Carta de Servicios ofertados a los turistas y elaboración del correspondiente listado de villas abiertas al público.

- difusión web a través de la implementación y gestión de portales específicos.

- creación de un punto de información y promoción de las villas vénetas.

- organización de actividades de formación e información dirigidas a los propietarios de villas.

- impulso de diversas iniciativas para la puesta en valor y promoción de las villas, como la elaboración de material informativo en diferentes idiomas, adaptado a las distintas formas de turismo y estrechamente vinculado con el resto de singularidades de la zona.

Paralelamente, por recomendación directa de la Administración regional, en el año 2009 se instituyó el "Coordinamento Veneto ville e dimore storiche" con el propósito dar respuesta a la necesidad de disponer de un interlocutor único con quien tratar los aspectos relativos a la promoción turística de las villas vénetas. Así, a partir de la unión de tres organizaciones previamente existentes (Asociazione ville venete, Ville Venete \& Castelli, y la sección Veneto de Dimore Storiche) se creó el "Coordinamento" para facilitar el diálogo y el intercambio de opiniones entre propietarios de villas, tanto aquellos que ya las tenían abiertas al público como aquellos que estaban interesados en incorporarse a la nueva iniciativa (Canato, 2013: 15).

Ese mismo año, fruto del citado plan, fue adoptada la "Carta de Servicios", pensada con objeto de dar respuesta a la necesidad de establecer una serie de reglas y principios para crear en torno a la villa un nuevo producto que pudiese ser ofertado en el mercado turístico ${ }^{11}$.

Para lograr tal cometido, la carta definía unos estándares mínimos de calidad y de servicios disponibles en las villas que debían ser respetados por los propietarios interesados en formar parte del proyecto, los cuales debían formalizar su compromiso adhiriéndose a dicha carta. De este modo, la carta pretendía por un lado identificar la disponibilidad de villas para ofertar al turista, y por otro favorecer un turismo de calidad regulando al mismo tiempo una serie de parámetros con el fin último de permitir un uso responsable y garantizar su disfrute por parte de la colectividad (Canato, 2013: 20).

Profundizando en el contenido de la carta, ésta se encontraba organizada en varios apartados. En el primero eran abordados los principios fundamentales, que enumeraban cuáles eran los condicionantes para poder adherirse. La exigencia principal era la de formar parte del catálogo elaborado por el "Istituto Regionale Ville Venete", en el que se encontraban inscritas todas las villas consideradas de interés, estuviesen o no prote-

10 https://www.regione.veneto.it/web/turismo/ville-venete. [Página web], consultado: 22 de febrero 2016.

11 Deliberazione della Giunta regionale n. 2390 del 4 agosto 2009. 
gidas por la legislación correspondiente en materia de cultura. Igualmente, era necesario el compromiso de garantizar una continuidad y regularidad en la apertura de la villa.

Seguidamente eran abordados los requisitos mínimos que los propietarios que suscribían la carta debían cumplir para permitir, por un lado a los operadores turísticos y agencias de viajes la promoción eficaz del producto turístico y, por otro lado a los turistas ver en las villas del Véneto un destino de calidad. En este sentido, era necesario concretar las partes de la villa que iban a ser abiertas al público. No tenía por qué ser toda la villa, por lo que el propietario que desease abrir al público sólo una parte lo podía hacer, de hecho se contemplaba la posibilidad de hacer visitable sólo el jardín y la parte externa de la villa. También se fijaban unos requisitos en el sentido de que se debía tener un horario prefijado a respetar -avisando a los operadores turísticos en caso de imposibilidad momentánea de acceso- y una tarifa de precios conocida por el usuario.

En tercer lugar, establecía unos compromisos y estándares de calidad, que abordaban aspectos relacionados con la gestión de reservas y de hospitalidad en el recibimiento al cliente, destacando respecto a éste último la disposición de un punto de información con material informativo de la historia de la propia villa y también de las villas vecinas o de los eventos culturales realizados en la localidad. Finalmente, daba una serie de recomendaciones acerca del servicio de aparcamiento, guardarropa, aseos, etc. y abordaba las hojas de reclamaciones a poner a disposición de los visitantes.

Con posterioridad la "Carta de Servicios" fue actualizada, creándose en 2010 una "Carta de Servicios Simplificada" para aquellas villas que, estando incluidas en el catálogo del IRVV, desarrollaban actividades de empresa abierta al público como complejo turístico, restauración u otros, ya que se les presuponía una estructura organizada, motivo por el cual se les exigían menores requisitos ${ }^{12}$.

Otra de las medidas propuestas por el plan de valorización turística era la generación de material informativo. Así que, tras la "Carta de Servicios", fue abordada por la "Direzione Regionale per i Beni Culturali del Veneto", el "Istituto Regionale Ville Venete", y el "Coordinamento Veneto Ville e Dimore Storiche", la elaboración de diversos itinerarios turísticos y culturales, en los que obviamente tenían una condición preferente para ser incorporadas aquellas villas adheridas a la mencionada Carta (Figura 3). Dichos itinerarios fueron difundidos a través de diversos sitios web creados específicamente para la promoción y la difusión de las villas vénetas, eficaces instrumentos de comunicación y de información que permitían al visitante conocer los servicios ofertados en cada villa proporcionando al mismo tiempo una conexión directa con los propietarios y/o los operadores turísticos (http://www.veneto.eu/, http://www.villevenete.net/ y http://www.irvv. net/it/d/ville-aperte.html).

No obstante, dado que los intereses particulares de cada turista podían ser de lo más variados, dichas plataformas permitían también crear itinerarios personalizados atendiendo desde al simple criterio de proximidad geográfica o servicios disponibles -entre ellos transporte público o visitas guiadas-, a otros aspectos más complejos relacionados con las propias inquietudes del visitante, fuesen estas la naturaleza, cultura, gastronomía, religión, deporte, familia, alojamiento, etc.

12 Deliberazione della Giunta regionale n. 1809 del 13 luglio 2010. 


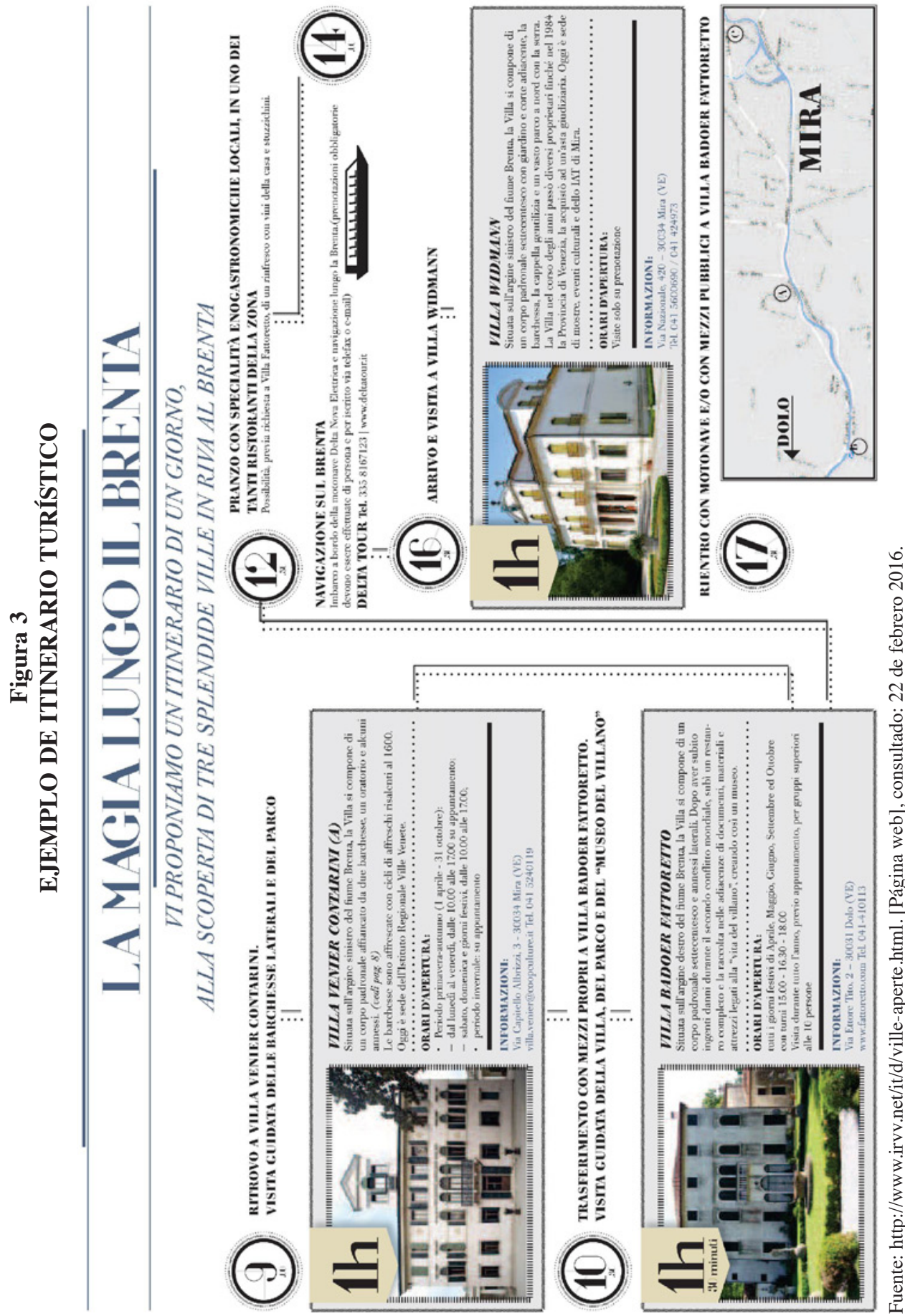


Por último, en el marco de la actividad formativa e informativa a los propietarios de villas, la experiencia véneta era ya amplia, pues la "Regione Véneto" y el "Istituto Regionale Ville Venete" venían promoviendo desde años atrás encuentros anuales sobre las villas con la finalidad de dar a conocer a sus propietarios la actividad desarrollada por la Administración, y sobre todo para crear un diálogo entre todos los interesados. En concreto el año 2011 fue organizado un encuentro bajo el lema "La valorización de un nuevo producto turístico: Las villas Vénetas" con objeto de reunir a propietarios, operadores turísticos, gestores de servicios culturales y representantes institucionales para abordar el potencial de las villas como bienes culturales en torno a los cuales organizar una explotación turística eficaz y sostenible.

\section{LAS VILLAS DEL CAMPO DE CARTAGENA: UN BIEN CULTURAL CON POTENCIAL TURÍSTICO}

La ciudad portuaria de Cartagena cuenta con un importante patrimonio arquitectónico en el que ocupan un lugar privilegiado, por un lado, los yacimientos arqueológicos, y por otro, los edificios de tendencias modernistas y eclécticas que adornan su centro histórico. Junto a ellos, otros elementos significativos son las construcciones defensivas de la antigua capital departamental, que presenta un conjunto único de fortalezas, castillos y baterías distribuidos a lo largo de su costa.

Porque el poder de seducción del patrimonio se fundamenta en la necesidad de mostrarse entero y con todos sus rincones desconocidos, más allá del centro histórico y de las construcciones militares, ambos protagonistas principales con un papel sin duda bien merecido, cabe destacar también las numerosas villas que se encuentran dispersas por el campo de Cartagena. Estas villas, fruto de una pujante burguesía de finales del siglo XIX, por su empaque significativo y representatividad formal así como por su roturada naturaleza próxima, se han convertido en hitos arquitectónicos y naturales que dominan el paisaje agrario de la comarca.

Dicha parte del patrimonio arquitectónico cartagenero que se adentra serpenteando hacia el interior se encuentra situada poco menos que en un reducido paraíso semioculto, y merece la oportunidad de ser descubierta, aunque la razón se incline por otros rumbos influida por él, a veces traidor, vicio de la costumbre de centrar el mayor el interés en los conjuntos históricos de las ciudades.

\subsection{Las villas de la Comarca del Campo de Cartagena y su contextualización histó- rica en el ámbito español}

España no ha sido ajena a la construcción de villas, de hecho, existen en su territorio restos arqueológicos que atestiguan la existencia de este tipo de edificaciones desde los primeros momentos de la dominación romana.

Posteriormente, tras la época medieval fueron configurándose a lo largo de su costa mediterránea diversos núcleos de producción agraria que se apropiaron, en la medida de lo posible, de la ideología de la villa en su versión rústica como centro desde el que gestionar una explotación agrícola y como lugar de recreo. En cambio, el desarrollo del 
palladianismo en este país ha sido escaso (Navascués, 1987: 13). A pesar de ello, aunque son pocos los testimonios de villas renacentistas y barrocas existentes en España, en la vivienda señorial edificada en el campo de la Región de Murcia a partir del siglo XVIII se perciben rasgos que reflejan la influencia de la arquitectura véneta (Hervás, 1989: 25). De ellos destaca la forma y proporción armónica de las edificaciones, con fachadas de una excepcional elegancia basada en la sencillez y simetría compositiva.

No hay que olvidar que la proximidad geográfica crea vínculos entre distintos países, determinando unas afinidades que, en el caso de la arquitectura desembocan en ciertas semejanzas en las tipologías arquitectónicas (Segovia, 1989: 15). Así, Italia y España, como países ubicados en el arco mediterráneo, presentan numerosos puntos de coincidencia climática, topográfica, agrícola, comercial y cultural (Figura 4).

Además, ya en la segunda mitad del siglo XIX y principios del XX tuvo lugar un nuevo periodo de esplendor de la historia de esta tipología arquitectónica en Murcia con la construcción de numerosas villas para la aristocracia y burguesía terrateniente de Cehegín, Caravaca, Lorca, Totana, Mula y, sobre todo, de Cartagena (Pérez Rojas, 1986: 257).

Esto ha tenido fiel reflejo en la expresión arquitectónica de la comarca del Campo de Cartagena (Figura 4), donde dispersas por la amplitud de tu territorio se encuentran toda una serie villas modernistas y eclécticas que, al igual que las vénetas, tienen una esencia atractiva e inspiradora que las diferencia de las construcciones rurales convencionales.

\section{Figura 4}

VILLAS DE CARTAGENA, SIGLOS XIX-XX
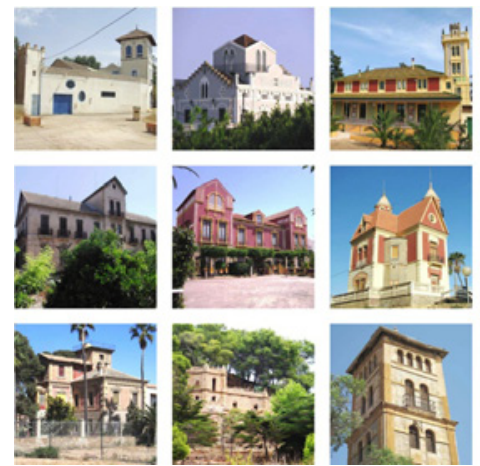
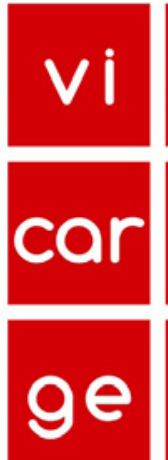
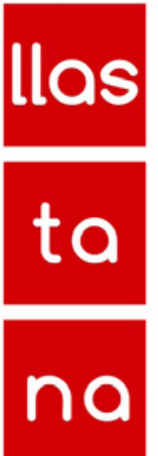
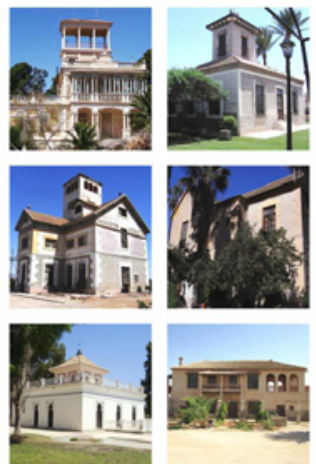
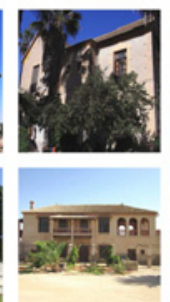
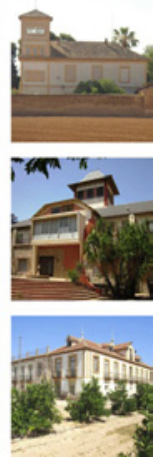

Elaboración propia.

Estas villas tienen su origen principalmente en dos impulsos de diferente motivación: socio-económica y urbanística. Por un lado, el pronunciado desarrollo económico experimentado en la comarca asentado sobre el sector minero-metalúrgico y el intenso tráfíco portuario por él generado (López y Pérez de Perceval, 2010: 224), así como la revitalización del arsenal, provocó que la ciudad quedase constreñida al recinto amurallado, resultando incapaz de integrar a una población creciente (Ródenas, 2006: 118). Hecho que, junto a la insalubridad del entorno y los graves destrozos producidos durante la revolución 
cantonal de 1873 llevaron a la reconstrucción de su centro histórico y la adopción de medidas de mejora (Egea, 1996: 312). Por otro lado, como consecuencia de este crecimiento se reestructuró de forma clara la jerarquía social de la ciudad, donde pronto surgió una potente burguesía deseosa de alcanzar el ennoblecimiento y la consolidación de su estatus. Así, para cumplir sus objetivos, insistió en mostrar su pujanza y poder económico a través de consumos suntuarios, y principalmente de la arquitectura.

De este modo, la ciudad experimentó una gran transformación siguiendo las nuevas tendencias artísticas del momento gracias a la aportación de la sociedad burguesa que, culta e interesada por el arte, recurrió a la nueva arquitectura como medio para reafirmar su distinción social y hacer ostentación de su riqueza. Además, una vez subsanados los problemas elementales de hacinamiento y salubridad, aparecieron nuevas demandas derivadas de la evolución social dentro del modelo anterior que pretendían el acceso a condiciones de vida -residencia y esparcimiento- que superasen los requisitos básicos.

Se da también la circunstancia de que tras los sucesivos procesos de desamortización amplias extensiones de tierras fueron subastadas pasando a manos privadas, por lo que parte de las fortunas obtenidas se invirtieron en explotaciones agrícolas (Martínez, 2002: 233). Lo que posibilitó que el campo no quedara ajeno a esta tendencia de recurrir a los arquitectos más significativos del momento para proyectar imponentes villas. En dichas fincas el burgués buscaba, además de una fuente complementaria de ingresos, un lugar donde alejarse durante los fines de semana y meses de verano del bullicio de la ciudad y dedicarse al descanso y las relaciones sociales, disfrutando de las vistas y el ambiente saludable y fresco que proporcionaban sus jardines, testigos de numerosas veladas y fiestas (Ramos, 2006: 94).

La oferta de villas es tan apasionante como extensa. Aparecen dispersas por la comarca, pero sobre todo en las diputaciones de El Plan, Pozo Estrecho y San Félix, abarcando algunas localidades que ya son término municipal de Fuente Álamo y Torre-Pacheco. Además, hablando de arquitectura pintoresca, no podemos pasar por alto toda una serie de construcciones que a modo de quinta de recreo se construyeron en este periodo a lo largo de la costa del Mar Menor, principalmente en San Pedro del Pinatar y San Javier, respondiendo a la moda de los baños de mar, germen del actual concepto de veraneo de sol y playa (Beascoechea, 2002: 182).

\subsection{Análisis de las villas del Campo de Cartagena. Sus componentes patrimoniales}

La multiplicidad de registros estilísticos y soluciones constructivas que depara el conocimiento de estas manifestaciones arquitectónicas enriquece el panorama descrito, signo evidente de un mundo vivo en este campo que permitió satisfacer las demandas de unos clientes que no sólo rivalizaban en sus residencias domésticas de ámbito urbano sino también en la lejanía del campo o de la huerta. Se trata de factores polivalentes que pueden explicar el fenómeno y lo hacen más atractivo para el visitante. A veces se presenta también como un patrimonio desconocido, porque algunos de sus interiores pueden llegar a sorprender por su depurado lenguaje ornamental o la variedad y riqueza de sus materiales de acabado cuando se han conservado. Incluso cabe señalar que a su belleza se une la autoría relevante de algunas de ellas. 
A pesar de que el modernismo fue un movimiento fuertemente enraizado en la ciudad de Cartagena, donde partiendo del modelo catalán acabó adquiriendo una identidad propia derivando en el denominado modernismo cartagenero, en las villas el estilo predominante fue el eclecticismo. Si bien en ellas el modernismo se apunta en algunos motivos decorativos como la temática vegetal y la cerámica multicolor.

Esta mezcla de estilos comienza a vislumbrarse en las primeras villas pertenecientes a la etapa final del siglo XIX, que no acaban de perder la esencia clasicista, constituyendo las construidas a comienzos del novecientos los ejemplos más representativos del eclecticismo. En la mayoría de estas obras se aprecia ya una mayor ornamentación de las fachadas principales, más cuidadas en su diseño, con embocaduras más realzadas, cornisas más resaltadas y mayor contraste de colores.

En este sentido, la estética islámica tuvo una cierta formulación en esta arquitectura doméstica. Interés sin duda justificado por su carácter principal como lugar de recreo. Recordemos que el neomudéjar estaba ampliamente representado en Murcia en edificios recreativos como el Casino de Murcia y los Baños de Archena y Fortuna. Igualmente los catálogos y láminas de arquitectura, ampliamente difundidos en la época por toda Europa tienen mucho que ver con la moda de tejados de gran pendiente y prolongados aleros con adornos de madera que se extiende entre las villas.

Por otro lado, atendiendo a la tipología, casi todas estas edificaciones disponen de la característica torre de la arquitectura rural del Sureste español, remarcando el carácter dominante de la finca y permitiendo gozar de una vista de gran extensión (Figura 5). Cabe mencionar que en el marco de referencia de una clase burguesa que hace gala de una vieja mentalidad, resulta coherente que la atención espiritual saltase a un primer plano, por lo que en algunas fincas de Cartagena podemos encontrar una capilla o incluso una ermita.

Figura 5

VILLA TORRE LLAGOSTERA. CARTAGENA, 1903-1918

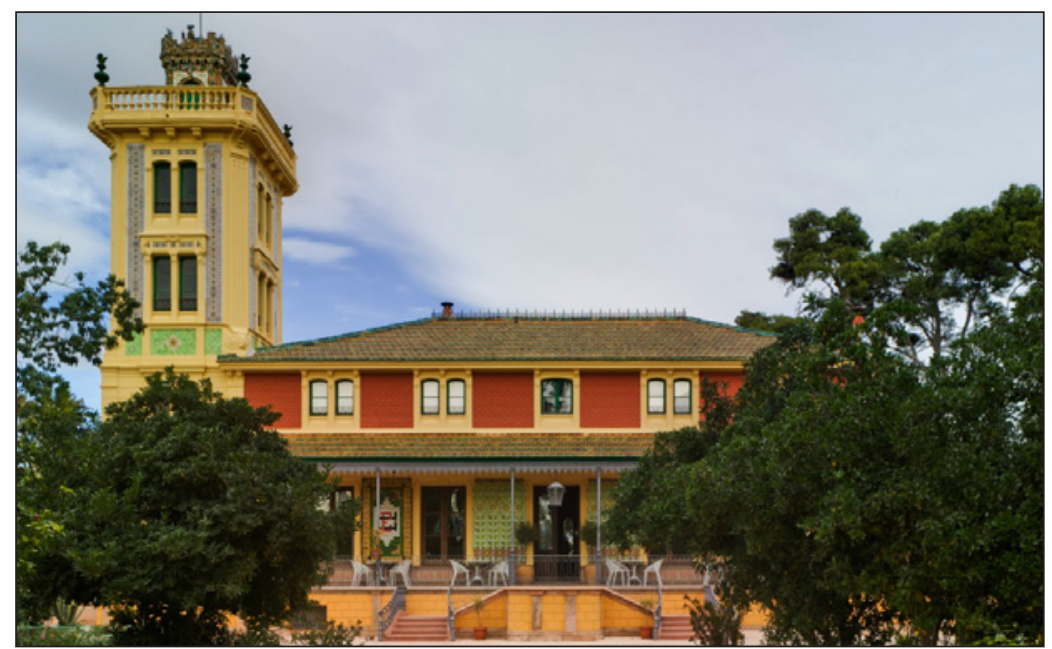

Fotografía del autor. 
Otro factor que enriquece el panorama descrito es su profunda vinculación con la naturaleza. Debido a la particularidad de la villa de cubrir una necesidad que no es sólo material, sino también ideológica, la de ambientar paisajísticamente un lugar para disfrutar de una vida más natural, la inserción de la edificación en el entorno se encontraba acentuada mediante la reorganización de los elementos vegetales teniendo presente que un jardín necesita ciertos recursos arquitectónicos (Figura 6). Así que muchas de las fincas disponían de amplios jardines pintorescos, con paseos adornados por arbustos, bancos, estanques y fuentes que ponían la nota de frescor y de aire puro en los estíos áridos del levante.

\section{Figura 6 \\ JARDÍN DE VILLA TORRE LLAGOSTERA}

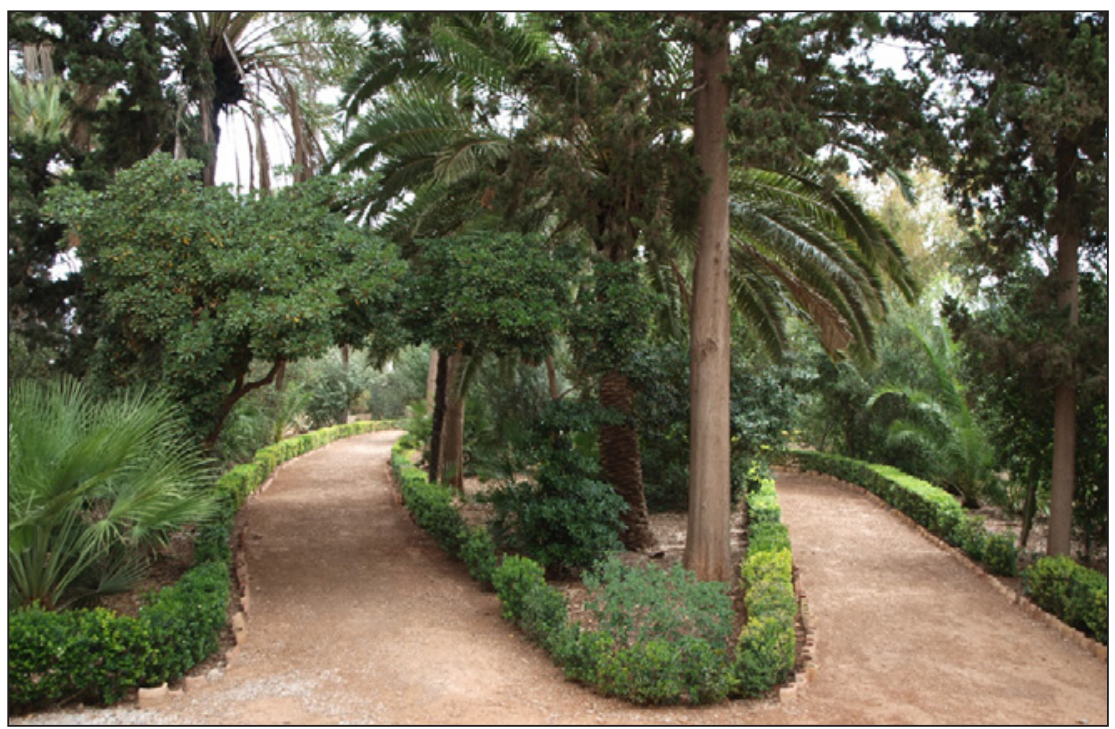

Fotografía del autor.

Además, en estos asentamientos rurales es frecuente encontrar también otras construcciones ligadas a la vida y la actividad agrícolas, desde cuadras, establos, graneros y almacenes de aperos, a la residencia de los trabajadores encargados del servicio doméstico, las tareas agrícolas, el cuidado de los animales y la vigilancia de la finca. Una arquitectura rural no firmada por arquitectos, pero igualmente interesante por estar levantada siguiendo el tradicional saber constructivo, utilizando materiales y métodos transmitidos de generación en generación.

En definitiva, se trata de un patrimonio que va de las grandes obras, a otras más modestas, un conjunto que abarca el arte de la construcción, la agricultura y la jardinería, todos en su sentido más amplio, configurando un paisaje cultural característico e irrepetible que merece ser descubierto, del que estas líneas aportan las principales claves para ayudar a su conocimiento y comprensión globales. 


\subsection{La valorización turística de las villas del campo de Cartagena: una necesidad inaplazable}

El paso del tiempo unido a las evoluciones sociales, así como a la mano del hombre, siempre transformadora, ha puesto en peligro una parte importante de las citadas villas, muchas de las cuales se encuentran en la actualidad deshabitadas y vienen sufriendo en los últimos años un progresivo deterioro. Lamentablemente, esto ocurre a pesar de que la Administración ha reconocido el valor de estas singulares edificaciones sometiéndolas a medidas de protección específicas a través de la legislación existente en materia de cultura.

En consecuencia, poco a poco se está perdiendo esta riqueza, ya sea por su abandono frío y premeditado, con desprecio a la historia, o por tratarla -simplemente por desconocimiento- sin ninguna consideración y sin darle el cuidado que se merece.

Por este motivo, resulta ineludible abordar con criterios de rigor científico nuevas estrategias, no sólo desde la perspectiva hacia su conservación, sino desde un enfoque mucho más efectivo, el de conocimiento y puesta en valor, pues es precisamente el olvido el responsable de la incuria que las ronda y que ya ha denostado a importantes creaciones arquitectónicas.

Tampoco debe perderse de vista el carácter complementario de la explotación turística con las políticas para la tutela del patrimonio cultural, que tras la protección de los bienes considerados de interés requieren de la adopción de medidas para su puesta en valor, entendida como la necesaria vinculación entre el patrimonio y la sociedad, pues toda medida de protección y conservación que se establezca sólo cobra sentido si va acompañada de otras medidas que al final conduzcan a que un número cada vez mayor de ciudadanos pueda conocer, contemplar y disfrutar las obras que integran el patrimonio.

Indudablemente, el turismo aporta una serie de ventajas al patrimonio cultural como la entrada de dinero, ya sea a través de la venta de tickets o de la obtención de concesiones y ayudas, lo que proporciona fondos con los que sufragar las costosas tareas de conservación y restauración, garantizando así su transmisión a las generaciones futuras. Al mismo tiempo, el turismo puede suponer un impulso de los valores culturales y tradicionales al fomentar la artesanía o generar otras actividades económicas alternativas. Por otro lado, esa retribución económica junto con el interés mostrado por los turistas hacia el patrimonio cultural de una zona suscita entre la ciudadanía el interés por la conservación de dichos bienes, por lo que indirectamente contribuye a la formación de la identidad cultural de la sociedad.

\section{LAS VILLAS DE CARTAGENA: LA PROMOCIÓN TURÍSTICA DE UN BIEN CULTURAL}

Llegados a este punto, es el momento de pensar qué se puede hacer para que las villas de Cartagena sean incorporadas a la oferta turística de la Región de Murcia.

Sin duda alguna, el turismo se perfila desde hace años como una estrategia fundamental para la gestión de los bienes tanto culturales como naturales, por lo que se presenta como un instrumento decisivo para luchar contra la pérdida de las villas de Cartagena. De manera que el reconocimiento de las villas como un bien cultural constituye un factor 
clave para convertirlas en protagonistas de una propuesta de turismo cultural. Ahora bien, ese potencial sólo puede ser desarrollado si las villas son incorporadas en un proyecto de mayor envergadura que las valorice no sólo como un edificio atractivo desde el punto de vista artístico, sino en sus múltiples aspectos: como paisaje, como cultura, como historia y como modo de vida.

Evidentemente, existe el riesgo de la falta de colaboración del propietario, que debe conocer el valor cultural de su villa y comprender que la sociedad tiene derecho a disfrutarla, siempre desde el respeto al privado. Pero también es cierto que pesa sobre él la obligación de mantenerla, por lo que la explotación turística puede presentarse como el incentivo financiero para aliviar las costosas intervenciones de conservación necesarias. Además, se cuenta con la ventaja de la experiencia previa puesta en marcha en Italia hace ya varios años que ha demostrado que el turismo de villa es una realidad constatable.

De modo que, para lograr tal objetivo, es necesario conocer las fortalezas y debilidades del conjunto de villas existentes en la comarca que permitan hacer de ellas un elemento de carácter identitario para la sociedad local y de atractivo turístico para los visitantes.

\subsection{La explotación turística de las villas de Cartagena en la actualidad}

Como punto de partida a cualquier estrategia que tenga por objeto la promoción de las villas de Cartagena como un bien cultural en torno al cual organizar una actividad turística, se precisa analizar la situación actual de este patrimonio arquitectónico y conocer en qué medida se encuentra preparado para acoger a los visitantes. Afortunadamente, a este respecto desde los inicios del siglo XXI han sido diversas las iniciativas llevadas a cabo para la recuperación y apertura al público de varias de las villas distribuidas por el campo de Cartagena.

Uno de los primeros ejemplos de recuperación se encuentra en la quinta San Sebastián, conocida como Casa del Reloj, que en el año 1995 fue declarada Bien de Interés Cultural (B.I.C.) y tras años de abandono fue rehabilitada como restaurante, acondicionando para ello todas las estancias de la vivienda -incluso de la planta noble-como salones, mientras que la buhardilla es utilizada como espacio de exposiciones. Desafortunadamente, el jardín que rodea la villa no ha sido recuperado, conservándose únicamente un paseo en cruz flanqueado por palmeras que marca los caminos de acceso hacia la casa.

Igualmente para restauración ha sido recuperada la Torre Llagostera también conocida como el Huerto de las Bolas, declarada B.I.C. en el año 2005 y adquirida en 2007 por el Ayuntamiento, que posteriormente sacó a concurso público la concesión del uso privativo de la edificación principal para dedicación hostelera. En esta ocasión, sólo han sido acondicionadas para su apertura al público las estancias de planta baja, respetando todos los espacios originales en la medida de lo posible, incluso el baño. Por otra parte, el jardín, que cuenta con numerosos elementos arquitectónicos decorados con cerámica modernista, ha sido recuperado y convertido en jardín botánico municipal.

Torre Antoñita, es otra muestra de una casa solariega reorientada como lugar para celebración de enlaces y eventos. Aunque la villa no ha sido declarada B.I.C. está igualmente protegida por las normativas cultural y urbanística, que sólo permiten pequeñas modificaciones de adaptabilidad a los nuevos usos y costumbres pero siempre conser- 
vando sus estructuras fundamentales, distribuciones y configuraciones espaciales. Por tal motivo, dadas las menores dimensiones de la residencia principal respecto a los ejemplos anteriores, para disponer de los amplios espacios requeridos por este tipo de acontecimientos han sido acondicionadas las construcciones de servicio agrícola. Asimismo, los espacios exteriores han sido adaptados para tal fin, aunque lamentablemente a pesar de haber conservado los elementos arquitectónicos existentes, la intervención ha supuesto una pérdida significativa de la esencia atractiva del jardín histórico al abusar de la utilización de algunos materiales discordantes como el césped artificial y el pavimento de hormigón.

Villa Esperanza, con un grado de protección menor que permite cualquier adaptación o modificación con la condición de que se conserven las fachadas como formas configuradoras del espacio urbano, es otro ejemplo más a añadir a la lista de edificios que tras años de abandono ha sido rehabilitado, aunque desgraciadamente no se han recuperado los prolongados aleros profusamente decorados con adornos de madera, tan característicos de las villas de Cartagena. En este caso el edificio alberga una cafetería, siendo sólo accesibles al público algunas dependencias de planta baja y también el jardín.

Dejando a un lado el sector servicios para pasar a estrategias de recuperación y adecuación con destino público encontramos algunos casos, como la rehabilitación de la Casa Moruna o Casa de Diego Pérez Espejo, cuya intervención ha sido financiada a través de subvenciones de la Dirección General de Cultura y del Plan de Inversiones en Barrios y Diputaciones del Ayuntamiento de Cartagena para disponer en la localidad en que se ubica de un espacio multiusos para los vecinos.

Ya en la costa del Mar Menor, se puede citar el palacio del Barón de Benifayó, sede desde el año 2008 del Museo Arqueológico y Etnográfico de San Pedro del Pinatar.

Pero además de todas estas iniciativas, en su mayoría impulsadas por la Administración, resulta necesario mencionar aquellas familias que han conservado las fincas hasta la actualidad manteniendo su ambiente original, como es el caso de Torre Nueva, que es ofertada como villa de descanso proporcionando servicio de alojamiento principalmente en los meses de verano y, en general, durante los períodos de vacaciones.

\subsection{La explotación turística de las villas de Cartagena. Una realidad posible}

Las villas de Cartagena son un patrimonio cultural de inmenso valor y tienen un gran atractivo para poder desarrollar un rol fundamental en la elección de la demanda turística. Ahora bien, este producto turístico no puede ser ofertado sin previamente establecer un diálogo directo con las instituciones que se ocupan de la tutela de este patrimonio, que tiene la urgente necesidad de ser restaurado y, sobre todo, de ser valorizado. Pues una villa puede ser recuperada, pero si no es puesta en valor, ésta se convierte en un contenedor vacío, no vivido, que puede caer fácilmente de nuevo en el olvido y la degradación.

A este respecto, naturalmente el mejor uso de la villa, el más congruo y correspondiente a la naturaleza del edificio y su entorno, es el residencial, pudiéndose encontrar también soluciones intermedias de integración funcional que sean compatibles con su naturaleza doméstica. Si bien, no siempre resulta posible mantener su finalidad como 
vivienda de descanso y esparcimiento, o incluso recuperarlo en aquellas villas que fueron abandonadas, siendo necesario buscar una nueva utilidad para cada caso en particular que sea respetuosa con su destino original. Esta extensión del uso residencial viene representada por la función hotelera y de restauración, proporcionando una cocina y alojamiento enfocados a la tradición, recuperando así la función originaria de distensión de la villa.

Bajo esta perspectiva, el turismo se basa en la satisfacción de experiencias a través del consumo de lugares, en los cuales además de sus recursos turístico-culturales, comúnmente denominados componentes primarios, son necesarios ciertos elementos complementarios que conformen el sistema de acogida al visitante (Antón y González, 2007: 28).

Sin lugar a dudas, el reto es importante y la Administración no puede hacerlo sola sin la colaboración de los propietarios que, como principales sustentadores de esta iniciativa, deben involucrarse con una participación activa y amplia. Sin ellos, el proyecto sería una utopía.

Sólo una vez lograda esta premisa será el momento de crear el producto turístico Villas del Campo de Cartagena para ofertarlo a los operadores y agencias de viajes encargadas de gestionarlo, pues la masa de turistas debe ser correctamente atendida, y el propietario, como anfitrión, no se encuentra en condiciones de ofertar unos servicios claros. Para ello se requiere de gente preparada en condiciones de crear una red organizada y competitiva capaz de promover un producto turístico integrado tal y como hoy exige el mercado.

De hecho, incluso para los operadores turísticos es más complejo gestionar un turismo de villa que un turismo de ciudad o de mar. Cuando se habla de villa se habla de turismo itinerante, y gestionar a un turista itinerante respecto a un turista sedentario es mucho más difícil, pues requiere planificar cuidadosamente las distintas jornadas, los desplazamientos, el alojamiento, la restauración, etc. teniendo en cuenta que las villas se encuentran dispersas por toda la comarca. Además, el turista que opta por este tipo de experiencias es consciente de tales dificultades y cuando programa su viaje quiere conocer perfectamente el itinerario y tener la certeza de que las vacaciones van a transcurrir según lo previsto. En definitiva, aunque se trabaja con particulares, se trata de una iniciativa económica y como tal ha de ser planificada y gestionada (Canato, 2013: 18).

En segundo lugar, no se puede proponer al turista venir únicamente a visitar las villas de Cartagena, se debe añadir algo más. A este respecto, las últimas tendencias turísticas se encaminan ahora hacia un nuevo producto, el denominado paisaje cultural, que se dirige al conocimiento del territorio desde el punto de vista del paisaje, la cultura, la historia y las tradiciones de la zona. Precisamente por ello se hace necesario destacar los valores existentes en torno a las villas, para situarlas en las condiciones más favorables que logren generar una sensibilización entre la sociedad que permita darles un nuevo uso como recurso turístico.

Afortunadamente, las villas son compatibles con otros elementos típicos del Campo de Cartagena, ya que fueron desde sus orígenes no sólo lugares de placer y de tiempo libre, sino también lugares de trabajo y centros productivos agrícolas, lo que permite crear sinergias con el territorio en una estrategia coherente y de calidad. En el ámbito 
de este nuevo producto turístico, la villa se erige como una propuesta capaz de valorizar el campo de Cartagena en sus múltiples aspectos, dado que el potencial del territorio sólo puede ser explotado si se promueven aquellos elementos que por su diversidad y originalidad tienen mayor poder de atracción tanto a nivel nacional como internacional.

En este sentido, la orientación turística del patrimonio territorial se presenta como una eficaz herramienta de desarrollo local, especialmente para aquellos ámbitos rurales más desfavorecidos, en los que la dificultad de generar dinámicas de recuperación es mayor (Doctor, 2011: 278).

Por otro lado, se tiene ya un importante camino recorrido. Hay mucha gente que viene a la Región de Murcia desde primeros de abril hasta mitad de octubre, nos referimos al denominado turismo de sol y playa, que hace que durante dicho periodo el sector servicios se encuentre en pleno rendimiento. Se trata de turistas, tanto internacionales -principalmente ingleses y alemanes- como nacionales, que eligen la costa levantina para pasar el periodo vacacional. Además, a ellos hay que sumar los numerosos pensionistas que fijan su residencia en la costa murciana durante la mayor parte del año motivados por el buen clima. Otra tipología de visitante es el turista cultural que viene a ver cosas concretas o particulares. A este hay que demostrarle que en Cartagena hay otras posibilidades, no sólo modernismo, no sólo yacimientos arqueológicos, no sólo fortificaciones militares, sino también villas, jardines históricos y otros aspectos etnográficos.

Precisamente a este respecto, una práctica ampliamente utilizada en el marketing turístico consiste en conocer las motivaciones y los diferentes tipos de turistas que visitan un lugar, proporcionando información útil para el diseño de nuevos productos turísticos (Vértice, 2007: 38). De modo que el objetivo es diversificar la oferta turística, generar oportunidades que sean diferentes de las clásicas para que el turista que llega a la zona atraído por una motivación se anime a visitar el territorio, a conocer otras alternativas.

Partiendo de estas ideas, el siguiente paso es decidir qué cosas se pueden ofrecer a los turistas con los recursos existentes para que la experiencia resulte exitosa y se convierta en producto turístico. Una de las primeras ideas a tratar a la hora de crear el producto turístico villa es la de dar vida a esos contenedores, porque el turista cultural va en busca, cada vez más, de experiencias, de hacer cosas que normalmente no hace en su vida cotidiana (Uriely, 2005: 202). De manera que su curiosidad le lleva al descubrimiento de las excelencias artísticas, arquitectónicas y paisajísticas de lugares que no se adscriben a los tradicionales productos turísticos de playa, lago o montaña, pero al mismo tiempo desea entrar en contacto con otras culturas y estilos de vida.

Por otro lado, tampoco debe perderse de vista la posibilidad que ofrece la visita a las villas de conocer la historia y estudiar técnicas y materiales de construcción, así como la sistematización agraria tradicional, aspectos que seducen no sólo a arquitectos e ingenieros agrónomos, sino también a parte de la población.

La idea es que el turista no haga de la visita a la villa un paso exprés por la zona, sino que después pueda visitar también la iglesia del pueblo vecino, ir a degustar la cocina típica en otra villa transformada en restaurante o incluso pernoctar en una de ellas (Quan y Wang, 2004: 299). Sobre esto, se ha visto como se cuenta en la actualidad con cierta infraestructura al existir ya varias villas preparadas para recibir al visitante. 
Como señala Doctor (2011: 278), “en este contexto de globalidad o territorialidad del patrimonio, una herramienta ideal para conocerlo y valorarlo, paso previo imprescindible a su conservación efectiva, es el itinerario". De modo que otro de los objetivos es el de crear itinerarios turísticos del campo de Cartagena que, a partir de las villas hagan más conocidos y accesibles el resto de elementos singulares existentes en el entorno para que toda la zona pueda disfrutar de este desarrollo económico derivado del turismo cultural (Molina, Tudela y Guillén, 2014: 190).

Así, la cantidad y calidad de villas permitiría dibujar una ruta turística que podría variar, incluyendo unas u otras villas de acuerdo con el tiempo disponible y con los intereses particulares de los visitantes. Sin duda, habría que tener en cuenta que no todas las villas se podrían visitar: algunas de ellas son de propiedad pública, otras privadas; unas están en buen estado de conservación, otras casi en ruinas; a veces se trata de villas suburbanas, a veces están en pleno campo; en unas se podría tener acceso solamente el exterior, en otras también a los interiores. Además, en esta ruta indefinida, no sólo tendrían cabida las villas de finales del XIX y principios del XX, sino que se podrían incluir los modelos precursores de esta tipología residencial desde época romana con la visita a alguno de los yacimientos arqueológicos de la zona. Asimismo, el recorrido por caminos rurales permitiría al visitante contemplar los numerosos molinos de viento dispersos por el campo. Por otro lado, dado el origen minero de las grandes fortunas con que se sufragó la construcción de las villas, también se podría incorporar la visita a la Sierra Minera de Cartagena-La Unión, incluida en numerosos programas de puesta en valor, acercando al mismo tiempo al visitante al patrimonio industrial, que también resulta importante y merece la pena visitar.

\section{CONCLUSIONES}

Cuando se habla de patrimonio cultural no puede hacerse atendiendo exclusivamente a los aspectos históricos, artísticos, arquitectónicos, paisajísticos o de cualquier otra naturaleza cultural que resulten emblemáticos o significativos del mismo, sino que es necesario abordarlo desde un enfoque más amplio considerándolo también como un recurso económico (González Varas, 2015: 81). Hoy día nadie ignora que el turismo es una de las industrias más importantes del mundo ni que el patrimonio cultural forma parte de la vida actividad turística y por lo tanto puede ser explotado económicamente.

Lo que ocurre en el caso de las villas, es que muchas ocasiones se confunde la existencia de paisajes naturales, agrícolas y edificios de interés cultural, con la disponibilidad efectiva de productos, ignorando que tales recursos solamente constituyen la materia prima y que el producto turístico es la suma a dichos recursos de diversas actividades como la oferta gastronómica, los servicios y equipamientos generales en el entorno, la cualificación del personal que atiende a los turistas, etc. (Pardellas, 2008: 85).

A este respecto, la experiencia italiana en la gestión turística de las villas vénetas permite la definición de una metodología básica para la evaluación de las villas como recursos patrimoniales y su transformación en productos turísticos. Así, se parte de la idea de que el conjunto de atributos existentes en torno a las villas son recursos patrimoniales, naturales, etnográficos, etc. pero no turísticos, de modo que lo patrimonial y lo turístico 
se complementan pero no deben confundirse. Seguidamente se realiza un proceso de evaluación, planificación y puesta en valor, que como señala Ávila (2008: 229) constituye un estadio intermedio en el que el recurso patrimonial es transformado en activo turístico. Por último es abordado un plan de valorización turística a través de una serie de estrategias encaminadas a la promoción y difusión del producto turístico Villa.

Si bien, aún teniendo en cuenta las enormes posibilidades de beneficio que la promoción turística de las villas puede reportar tanto cultural como económicamente, por su propia ideología, la villa presenta una serie de particularidades que hacen que su gestión turística resulte especialmente compleja. Así, por un lado, su ubicación alejada del núcleo urbano dificulta su inclusión en la oferta turística de las ciudades, lo que obliga a buscar en su entorno próximo el conjunto de elementos que permitan constituir un itinerario turístico específico en torno a las villas. Por otro, y este es el principal reto a cumplir, su uso preeminentemente residencial privado precisa de estrategias de aproximación que, sin turbar la tranquilidad familiar, respeten el patrimonio y permitan ampliar su disfrute a la colectividad.

Es incuestionable que se trata de una iniciativa que requiere de una infraestructura cuyos costos no son ignorados, pero también es cierto que con el estudio realizado se ha demostrado que el conjunto de villas encierra un enorme potencial turístico capaz incluso de generar sinergias internacionales con otros destinos ya consolidados.

De modo que si se logra avanzar con precaución pero con paso firme e involucrando a los particulares en la recuperación y apertura al público de las villas del Campo de Cartagena se conseguirá, no sólo preservar este patrimonio, sino también impulsar la economía de la zona al incrementar la oferta turística y ofrecer al visitante experiencias diferentes.

\section{AGRADECIMIENTOS}

Este trabajo de investigación ha sido desarrollado gracias al Programa de formación y movilidad del personal docente e investigador de la Universidad Politécnica de Cartagena, que ha permitido la realización de una estancia de investigación en Italia.

\section{BIBLIOGRAFÍA}

ACKERMAN, J.S. (1990): The Villa. Form and idelogy of country houses. London, Thames and Hudson.

ANTÓN CLAVÉ, S. y GONZÁLEZ REVERTÉ, F. (2007): «La naturaleza del turista. De la turismofobia a la construcción social del espacio turístico», en A propósito del turismo. La construcción social del espacio turístico. Barcelona, Editorial UOC, pp. 11-34.

ÁVILA BERCIAL, R. (2008): «Metodología básica para la evaluación ponderada de los recursos patrimoniales en su proceso hacia la conversión en productos turísticos», en Turismo y desarrollo local. Cuenca, Ediciones de la Universidad de Castilla la Mancha, pp. 229-239.

AZZI VISENTINI, M. (1995): La villa in Italia. Quattrocento e Cinquecento. Milano, Electra. 
BARROSO GONZÁLEZ, M. y FLORES RUIZ, D. (2006): «La competitividad internacional de los destinos turísticos: del enfoque macroeconómico al enfoque estratégico», Cuadernos de Turismo, ${ }^{\circ} 17$, pp. 2-24.

BEASCOECHEA GANGOITI, J. M. (2002): «Veraneo y urbanización en la costa cantábrica durante el siglo XIX: las playas del Abra de Bilbao», Historia contemporánea, $\mathrm{n}^{\mathrm{o}} 25$, pp. 181-202.

BURGOS LUENGO, F.J. (2011): «¿Qué entendemos por villa romana?», Innovación y experiencias educativas, $\mathrm{n}^{\circ} 41$, pp. 1-16.

CANATO, C. (2013): La valorizzazione turistica di un prodotto culturale: le Ville Venete. Verona, Cierre.

CASATELLA, A. (2011): «Tutela e conservazione dei beni culturali nei Piani di gestione Unesco: i casi di Vicenza e Verona», Aedon [en linea], $\mathrm{n}^{\circ}$ 1. Disponible en: https:// www.rivisteweb.it/doi/10.7390/34951, [consultado: 22 de febrero 2016].

DI CESARE, F. [y otros] (2006): Valorizzazione di un prodotto culturale: le ville. Venezia, Risposte turismo srl.

DOCTOR, A.M. (2011): «El itinerario como herramienta para la puesta en valor turístico del patrimonio territorial», Cuadernos de Turismo, no 27, pp. 273-289.

EGEA BRUNO, P.M. (1996): «Los siglos XIX y XX», en Manual de historia de Cartagena. Murcia, Ayuntamiento de Cartagena, Universidad de Murcia, Caja de Ahorros del Mediterráneo, pp. 299-415.

GONZÁLEZ VARAS IBÁÑEZ, I. (2015): Patrimonio cultural. Conceptos, debates y problemas. Madrid, Cátedra.

HERVÁS AVILÉS, J.M. (1989): «La influencia italiana», en Arquitectura y color en Murcia. Murcia, Consejería de Política Territorial y Obras Públicas, pp. 19-30.

IPPOLITO, L. (2009): La villa del Novecento. Firenze, Firenze University Press.

LÓPEZ MORELL, M.A. y PÉREZ DE PERCEVAL VERDE, M.A. (2010): La Unión. Historia y vida de una ciudad minera. Córdoba, Almuzara.

MARTÍNEZ CARRIÓN, J.M. (2002): Historia económica de la Región de Murcia. Murcia, Editora Regional de Murcia.

MOLINA RUIZ, J., TUDELA SERRANO, M.L. y GUILLÉN SERRANO, V. (2014): «Potenciación del patrimonio natural, cultural y paisajístico con el diseño de itinerarios turísticos», Cuadernos de Turismo, n 34, pp. 189-211.

MORIANI, G. (2008): Palladio architetto della villa fattoria. Verona, Cierre.

NAIM, M. (2013): «Le Ville Venete: il contributo di Giuseppe Mazzotti», en Ville Venete un nuovo sguardo. Crocetta del Montello, Terra Ferma, pp. 77-87.

NAVASCUÉS PALACIO, P. (1980). «Reflexiones sobre Palladio en España», en Palladio. Madrid, Xarait, pp. XIII-XXIV.

PARDELLAS DE BLAS, X. (2008): «La gestión de los destinos turísticos rurales en un entorno de competitividad», en El Turismo rural. Madrid, Editorial Síntesis, pp.75-99.

PÉREZ ARANDA, J.L. (2015): «La responsabilidad social corporativa en turismo. Estado de la cuestión», ARA Journal, Vol. 5, n 1, pp. 63-80.

PÉREZ ROJAS, F.J. (1986): Cartagena 1874-1936. Transformación urbana y arquitectónica. Murcia, Editora Regional de Murcia. 
QUAN, S. y WANG N. (2004): «Towards a structural model of the tourist experience: an illustration from food experiences in tourism», Tourism Management, $\mathrm{n}^{\circ} 25$, pp. 297-305.

RAMOS FRENDO, E.M. (2006): «Aproximación a las villas de recreo de la familia Heredia en Málaga», Baética: Estudios de arte, geografía e historia, n 28 (1), pp. 91-108.

RÓDENAS LÓPEZ, M.A. (2016): Los orígenes de la vivienda social en la región de Murcia. 1900-1936. Las iniciativas de casas baratas en Cartagena y Murcia, (Tesis doctoral). Valencia, Universidad Politécnica de Valencia.

SÁNCHEZ ROJAS, M.C. (1986): «La villa renacentista (I)», Imafronte, no 2, pp. 5-24.

SEGOVIA MONTOYA, A. (1989): «Introducción», en Arquitectura y color en Murcia. Murcia, Consejería de Política Territorial y Obras Públicas, pp. 13-18.

SMITH, S. (1994): «The tourism product», Annals of Tourism Research, Vol. 21, n 3 , pp. 582-595.

TUCKER, K y SUNDBERG, M. (1988): International Trade in Services. Londres, Routledge.

URIELY, N. (2005): «The tourist experience. Conceptual Developments», Annals of Tourism Research, Vol. 32, n 1, pp. 199-216.

VALÉRY, P. (2004): Eupalinos o el arquitecto. (Trad. Carner, Josep). Murcia, Colegio Oficial de Aparejadores y Arquitectos Técnicos de Murcia (Original en francés, 1903). VERA BOTÍ, A. (2013): Arquitectura del Renacimiento. Elucidario. Murcia, Academia Alfonso X el Sabio.

VERTICE. (2007): Marketing turístico. Málaga, Vértice. 